\title{
Influence of phosphate source on preparation of zinc phosphate white pigments
}

\author{
Hiroaki Onoda ${ }^{1} \cdot$ Miho Haruki ${ }^{1}$
}

Received: 28 August 2015/Accepted: 22 November 2015/Published online: 5 January 2016

(C) The Author(s) 2015. This article is published with open access at Springerlink.com

\begin{abstract}
Photocatalytically active zinc oxide is used as a white pigment for cosmetics, leading to decomposition of a certain degree of sebum on the skin upon exposure to the ultraviolet radiation in sunlight. Herein, as novel white pigments for use in cosmetics, zinc phosphates were prepared from zinc nitrate and various phosphate compounds, viz., phosphoric acid, sodium di-hydrogen phosphate, disodium hydrogen phosphate, sodium pyrophosphate, or sodium triphosphate. The chemical composition, powder properties, photocatalytic activity, color phase, moisture retention, and smoothness of the zinc phosphates were evaluated. The obtained materials had $\mathrm{Zn} / \mathrm{P}$ ratios corresponding to those of zinc orthophosphate $\mathrm{Zn}_{3}\left(\mathrm{PO}_{4}\right)_{2}$, zinc pyrophosphate $\mathrm{Zn}_{2} \mathrm{P}_{2} \mathrm{O}_{7}$, and zinc triphosphate $\mathrm{Zn}_{5}\left(\mathrm{P}_{3}\right.$ $\left.\mathrm{O}_{10}\right)_{2}$. The photocatalytic activity of these zinc phosphate particles was low; thus, these pigments should not induce decomposition of sebum on the skin. All samples prepared in this study exhibited high reflectance within the range of visible light.
\end{abstract}

Keywords White pigment - Zinc phosphates . Photocatalytic activity $\cdot$ Particle shape

Hiroaki Onoda

onoda@kpu.ac.jp

1 Department of Informatics and Environmental Sciences, Kyoto Prefectural University, 1-5, Shimogamo Nakaragi-cyo, Sakyo-ku, Kyoto 606-8522, Japan

\section{Introduction}

Titanium dioxide and zinc oxide are used as white pigments for cosmetic applications [1]. These oxides are known to be photocatalytically active; therefore, cosmetics containing these pigments cause decomposition of a certain amount of sebum on the skin under ultraviolet radiation in sunlight. To repress this effect, several kinds of technical processes have been investigated and implemented. One such technique involves the use of composite particles with silicon oxide [2]. However, particulate materials such as silicon oxide are too hard for use on the human face. Instead, soft materials are required for use as white facial pigments. Microfine oxide particles are reportedly absorbed through the skin [3], highlighting the need for novel white pigments that are not absorbed by skin.

Phosphates have been used as ceramic materials, catalysts, fluorescent materials, dielectric substances, metalsurface treatments, detergents, food additives, in fuel cells, as pigments, and so on $[4,5]$. Phosphate materials are recognized to have high biocompatibility and are therefore expected to be useful as white pigments in cosmetics. White pigments that are not photocatalytically active are required for skin protection during cosmetic use. Furthermore, the moisture retention of the materials used in cosmetics is also important for preventing dry skin.

Phosphates are transformed to other forms of phosphates by hydrolysis and dehydration reactions at elevated temperatures $[6,7]$. Polyphosphate is included in the group of condensed phosphates. Polyphosphate has a chain structure in which the $\mathrm{PO}_{4}$ unit shares two oxygen atoms. Formation of these condensed phosphates is affected by the phosphorus/cation ratio, heating temperature, time, atmosphere, and so on [8-10]. Therefore, it is difficult to obtain a high yield of condensed phosphates. The properties of 
condensed phosphates differ from those of orthophosphates, and condensed phosphates can therefore be used as novel functional materials [11].

The particle shape and the size distribution of phosphates are important parameters for cosmetic pigment application. Spherical, homogenous particles are expected to spread well on the skin. However, overly small particles are unsuitable because the pigments may enter the pores of the skin. Generally, pigments with sub-micrometer dimensions are used in cosmetic applications. In earlier studies [12-14], we prepared titanium and zinc phosphate pigments with no catalytic activity. In this study, zinc phosphate, as a novel white pigment, is prepared from zinc nitrate and various phosphate sources, including phosphoric acid, sodium di-hydrogen phosphate, di-sodium hydrogen phosphate, sodium pyrophosphate, and sodium triphosphate. Because pyrophosphate and triphosphate were obtained as sodium salts, sodium di-hydrogen phosphate and di-sodium hydrogen phosphate were also evaluated as phosphate sources. The respective chemical compositions, powder properties, photocatalytic activity, color phases, moisture retention, smoothness of the obtained precipitates, and thermal products were studied for application of the developed pigments in cosmetics.

\section{Experimental}

In the course of our studies (unpublished data), it was found that commercial grade sodium pyrophosphate and sodium triphosphate contained a certain degree of orthophosphates. Therefore, in this study, sodium pyrophosphate and sodium triphosphate were synthesized from sodium di-hydrogen phosphate and di-sodium hydrogen phosphate. Sodium pyrophosphate, $\mathrm{Na}_{4} \mathrm{P}_{2} \mathrm{O}_{7}$, was synthesized by heating di-sodium hydrogen phosphate $\left(\mathrm{Na}_{2} \mathrm{HPO}_{4}\right)$ at $400{ }^{\circ} \mathrm{C}$ for $5 \mathrm{~h}$ [15]. Sodium triphosphate $\left(\mathrm{Na}_{5} \mathrm{P}_{3} \mathrm{O}_{10}\right)$ was synthesized by heating a mixture of disodium hydrogen phosphate $\left(\mathrm{Na}_{2} \mathrm{HPO}_{4}\right)$ and sodium dihydrogen phosphate $\left(\mathrm{NaH}_{2} \mathrm{PO}_{4}\right)$ with a $\mathrm{Na}_{2} \mathrm{HPO}_{4} / \mathrm{NaH}_{2}$ -

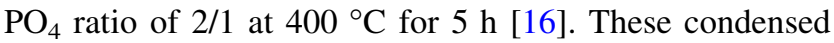
phosphates were formed according to the following equations:

$$
\begin{aligned}
& 2 \mathrm{Na}_{2} \mathrm{HPO}_{4} \rightarrow \mathrm{Na}_{4} \mathrm{P}_{2} \mathrm{O}_{7}+\mathrm{H}_{2} \mathrm{O} \\
& 2 \mathrm{Na}_{2} \mathrm{HPO}_{4}+\mathrm{NaH}_{2} \mathrm{PO}_{4} \rightarrow \mathrm{Na}_{5} \mathrm{P}_{3} \mathrm{O}_{10}+2 \mathrm{H}_{2} \mathrm{O}
\end{aligned}
$$

Zinc nitrate solution $\left(0.1 \mathrm{~mol} \mathrm{~L}^{-1}\right)$ was mixed with phosphoric acid, sodium di-hydrogen phosphate, or disodium hydrogen phosphate solution $\left(0.1 \mathrm{~mol} \mathrm{~L}^{-1}\right)$ in a molar ratio of $\mathrm{Zn} / \mathrm{P}=3 / 2$ at room temperature for more than $1 \mathrm{~h}$. This mixing ratio was determined based on the chemical composition of zinc orthophosphate, $\mathrm{Zn}_{3}\left(\mathrm{PO}_{4}\right)_{2}$.
Table $1 \mathrm{Zn} / \mathrm{P}$ ratios of precipitates and smoothness of samples prepared from various phosphate sources

\begin{tabular}{lllll}
\hline Sample & P resource & Zn/P ratio & MIU & MMD \\
\hline A & $\mathrm{H}_{3} \mathrm{PO}_{4}$ & 1.46 & 0.589 & 0.016 \\
B & $\mathrm{NaH}_{2} \mathrm{PO}_{4}$ & 1.40 & 0.610 & 0.005 \\
$\mathrm{C}$ & $\mathrm{Na}_{2} \mathrm{HPO}_{4}$ & 1.40 & 0.590 & 0.005 \\
D & $\mathrm{Na}_{4} \mathrm{P}_{2} \mathrm{O}_{7}$ & 0.91 & 0.547 & 0.011 \\
E & $\mathrm{Na}_{5} \mathrm{P}_{3} \mathrm{O}_{10}$ & 0.83 & 0.550 & 0.012 \\
\hline
\end{tabular}

Similarly, a $0.1 \mathrm{~mol} \mathrm{~L}^{-1}$ zinc nitrate solution was mixed with a $0.1 \mathrm{~mol} \mathrm{~L}^{-1}$ sodium pyrophosphate solution or sodium triphosphate solution in a molar ratio of $\mathrm{Zn} / \mathrm{P}=1 /$ 1 and 5/6, respectively. These mixing ratios were determined from the chemical composition of zinc pyrophosphate, $\mathrm{Zn}_{2} \mathrm{P}_{2} \mathrm{O}_{7}$, and zinc triphosphate, $\mathrm{Zn}_{5}\left(\mathrm{P}_{3} \mathrm{O}_{10}\right)_{2}$, respectively. The mixed solutions were adjusted to $\mathrm{pH} 7.0$ with ammonia solution or nitric acid. The precipitates were then filtered off, washed with water, and dried at room temperature over 3 days [14]. All chemicals were of commercial purity and were acquired from Wako Chemical Industries Ltd. (Osaka Japan) and used without further purification. The utilized conditions are summarized in Table 1.

A part of the precipitates was dissolved in hydrochloric acid solution. The ratios of phosphorus to zinc in the precipitates were also calculated based on inductively coupled plasma (ICP) analysis of these solutions using an SPS1500VR apparatus from Seiko Instruments, Inc. The crystalline phase compositions of these materials were analyzed using X-ray diffraction (XRD; MiniFlex; Rigaku Corp.) with monochromated $\mathrm{Cu}-\mathrm{K} \alpha$ radiation.

The shapes and sizes of the particles comprising the precipitates were estimated from the scanning electron microscopy (SEM; instrument: JGM-5510LV; JEOL Ltd.) images and particle size distributions. The particle size distributions of these materials were measured using a centrifugal precipitation particle size distribution analysis system (SA-CP3L, Shimadzu Corp.).

The cosmetic properties of the developed precipitates were estimated by analysis of the photocatalytic activity, color phase, moisture retention, and smoothness. The photocatalytic activity of the samples was assessed from the decomposition of methylene blue using $365 \mathrm{~nm}$ irradiation [17-19]. A $0.01 \mathrm{~g}$ portion of the sample was placed in $4 \mathrm{~mL}$ of methylene blue solution $\left(1.0 \times 10^{-5} \mathrm{~mol} \mathrm{~L}^{-1}\right)$ and this solution was then irradiated. The decrease in the absorption at about $660 \mathrm{~nm}$ was monitored over the course of $120 \mathrm{~min}$. The color of the phosphate pigments was estimated using ultraviolet-visible (UV-Vis) reflectance spectra acquired with a UV2100, Shimadzu Corporation 
instrument (reference compound: $\mathrm{BaSO}_{4}$ ). The moisture retention of the samples was evaluated by mixing $0.3 \mathrm{~g}$ of each sample with $0.1 \mathrm{~g}$ of water, and the weight loss was then evaluated at $50{ }^{\circ} \mathrm{C}$ (MS-70 Moisture Analyzer, A and D Instruments Co. Ltd.). The same weight loss over a longer time indicated high water retention of the samples. The particle smoothness was measured on artificial leather based on KES-SE objective evaluation of the surface friction (Kato Tech Co., Ltd.). The sample powders were spread onto the leather (load of sample: ca. $50 \mathrm{mg}$ ), and a sensor was then run over the powders (scan speed: $1 \mathrm{~mm} / \mathrm{s}$, area scanned: $3 \mathrm{~cm}^{2}$ ). The terms MIU and MMD, respectively, represent the slipping resistance $(\mu$, average value in a distance of $20 \mathrm{~mm}$ ) and roughness of the powders (fluctuation of average frictional coefficient). The values of MIU and MMD are dimensionless because these values are related to the coefficient of friction and scattering, respectively. The dispersions of the MIU and MMD values were 0.03 and 0.002 for triplicate measurements, respectively.

\section{Results and discussion}

\section{Chemical composition and powder properties of zinc phosphates}

Table 1 shows the $\mathrm{Zn} / \mathrm{P}$ ratios of the samples prepared with various phosphate sources. The samples prepared from $\mathrm{H}_{3} \mathrm{PO}_{4}, \mathrm{NaH}_{2} \mathrm{PO}_{4}$, and $\mathrm{Na}_{2} \mathrm{HPO}_{4}$ had a $\mathrm{Zn} / \mathrm{P}$ ratio of about 1.5, which corresponds to zinc orthophosphate, $\mathrm{Zn}_{3}\left(\mathrm{PO}_{4}\right)_{2}$. The samples prepared from $\mathrm{Na}_{4} \mathrm{P}_{2} \mathrm{O}_{7}$ and $\mathrm{Na}_{5} \mathrm{P}_{3} \mathrm{O}_{10}$ had $\mathrm{Zn} / \mathrm{P}$ ratios of 0.91 and 0.83 , respectively. These ratios correspond to the $1 / 1$ and $5 / 6$ ratios of zinc pyrophosphate, $\mathrm{Zn}_{2} \mathrm{P}_{2} \mathrm{O}_{7}$, and zinc triphosphate, $\mathrm{Zn}_{5}\left(\mathrm{P}_{3-}\right.$ $\left.\mathrm{O}_{10}\right)_{2}$, respectively.

Figure 1 shows the XRD patterns of the samples prepared with various phosphate sources. Peaks of zinc phosphate tetrahydrate, $\mathrm{Zn}_{3}\left(\mathrm{PO}_{4}\right)_{2} \cdot 4 \mathrm{H}_{2} \mathrm{O}$, were observed in the XRD patterns of the samples prepared with $\mathrm{H}_{3} \mathrm{PO}_{4}$, $\mathrm{NaH}_{2} \mathrm{PO}_{4}$, and $\mathrm{Na}_{2} \mathrm{HPO}_{4}$ [20]. Because the intensity of the zinc phosphate tetrahydrate peak for the sample prepared from $\mathrm{H}_{3} \mathrm{PO}_{4}$ differed from that of the samples prepared from $\mathrm{NaH}_{2} \mathrm{PO}_{4}$ and $\mathrm{Na}_{2} \mathrm{HPO}_{4}$, it is deduced that the sodium cation influenced the crystallinity of zinc phosphate tetrahydrate. On the other hand, unknown peaks were detected in the XRD patterns of the samples prepared with $\mathrm{Na}_{4} \mathrm{P}_{2} \mathrm{O}_{7}$ and $\mathrm{Na}_{5} \mathrm{P}_{3} \mathrm{O}_{10}$; these peaks could not be assigned due to the limited availability of data on condensed zinc phosphates. From the ICP and XRD data, $\mathrm{H}_{3} \mathrm{PO}_{4}, \mathrm{NaH}_{2}$ $\mathrm{PO}_{4}$, and $\mathrm{Na}_{2} \mathrm{HPO}_{4}$ yielded $\mathrm{Zn}_{3}\left(\mathrm{PO}_{4}\right)_{2} \cdot 4 \mathrm{H}_{2} \mathrm{O}$ as the main component, whereas $\mathrm{Zn}_{2} \mathrm{P}_{2} \mathrm{O}_{7}$ was obtained with $\mathrm{Na}_{4} \mathrm{P}_{2} \mathrm{O}_{7}$, and $\mathrm{Zn}_{5}\left(\mathrm{P}_{3} \mathrm{O}_{10}\right)_{2}$ was obtained with $\mathrm{Na}_{5} \mathrm{P}_{3} \mathrm{O}_{10}$.

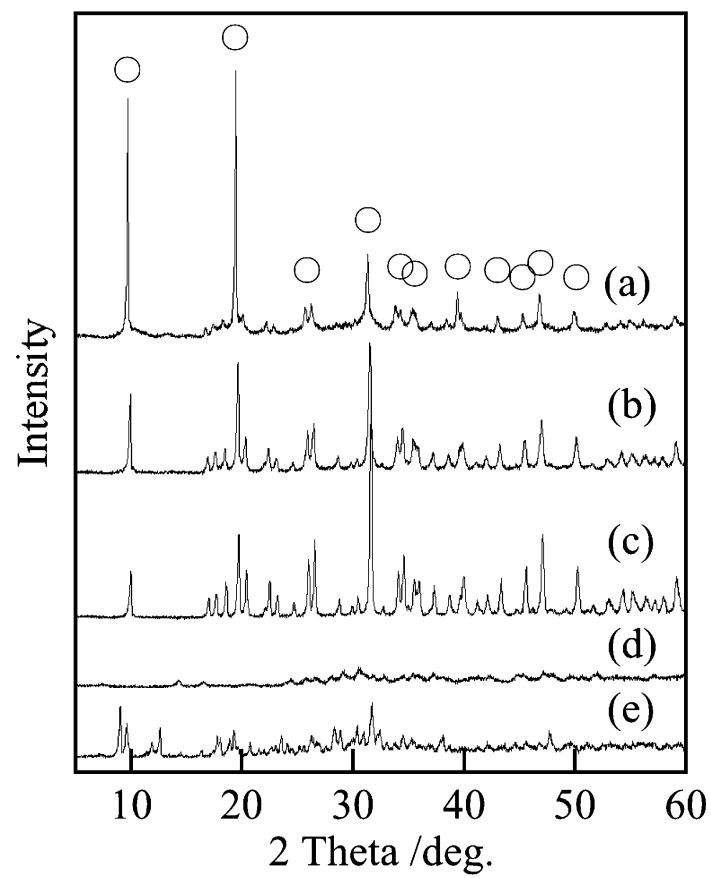

Fig. 1 XRD patterns of samples prepared from various phosphate sources: $a \mathrm{H}_{3} \mathrm{PO}_{4}, \quad b \quad \mathrm{NaH}_{2} \mathrm{PO}_{4}, c \mathrm{Na}_{2} \mathrm{HPO}_{4}, d \mathrm{Na}_{4} \mathrm{P}_{2} \mathrm{O}_{7}$, and $e \mathrm{Na}_{5} \mathrm{P}_{3} \mathrm{O}_{10}, \mathrm{O}: \mathrm{Zn}_{3}\left(\mathrm{PO}_{4}\right)_{2} \cdot 4 \mathrm{H}_{2} \mathrm{O}$

Spherical morphology of the particles is desirable for cosmetic applications. Figure 2 shows representative SEM images of the samples prepared with various phosphate sources. The samples prepared with $\mathrm{H}_{3} \mathrm{PO}_{4}, \mathrm{NaH}_{2} \mathrm{PO}_{4}$, and $\mathrm{Na}_{2} \mathrm{HPO}_{4}$ had some particles with flat surfaces. In contrast, large spherical particles were observed in the samples prepared with $\mathrm{Na}_{4} \mathrm{P}_{2} \mathrm{O}_{7}$ and $\mathrm{Na}_{5} \mathrm{P}_{3} \mathrm{O}_{10}$.

Small and homogeneous particles are suitable for cosmetic applications. However, overly small particles have a major shortcoming in that they enter the pores of the skin [3]. Generally, pigments with sub-micrometer dimensions are used in cosmetics. The standard size of white pigment particles used in cosmetics is difficult to determine because the size of the pores in skin is affected by factors such as age, gender, and climate. Furthermore, overly large particles are inappropriate for cosmetic purposes owing to cracking of their coating on the skin. It is therefore important to control the particle sizes of the pigment. Figure 3 shows the particle size distribution of the samples prepared with various phosphate sources. All samples prepared in this study had a large amount of particles with dimensions of over $10 \mu \mathrm{m}$. The sample prepared from $\mathrm{Na}_{4} \mathrm{P}_{2} \mathrm{O}_{7}$ had a small particle size as indicated in the SEM image (Fig. 2d); however, large particle sizes were observed in the particle size distribution analysis (Fig. 3d). This sample possibly underwent aggregation during the particle size distribution measurement. Generally, a smaller particle size was observed in the particle size distribution 
Fig. 2 SEM images of samples prepared from various phosphate sources: a $\mathrm{H}_{3} \mathrm{PO}_{4}$, b $\mathrm{NaH}_{2} \mathrm{PO}_{4}, \mathbf{c ~} \mathrm{Na}_{2} \mathrm{HPO}_{4}$, d $\mathrm{Na}_{4} \mathrm{P}_{2} \mathrm{O}_{7}$, and e $\mathrm{Na}_{5} \mathrm{P}_{3} \mathrm{O}_{10}$
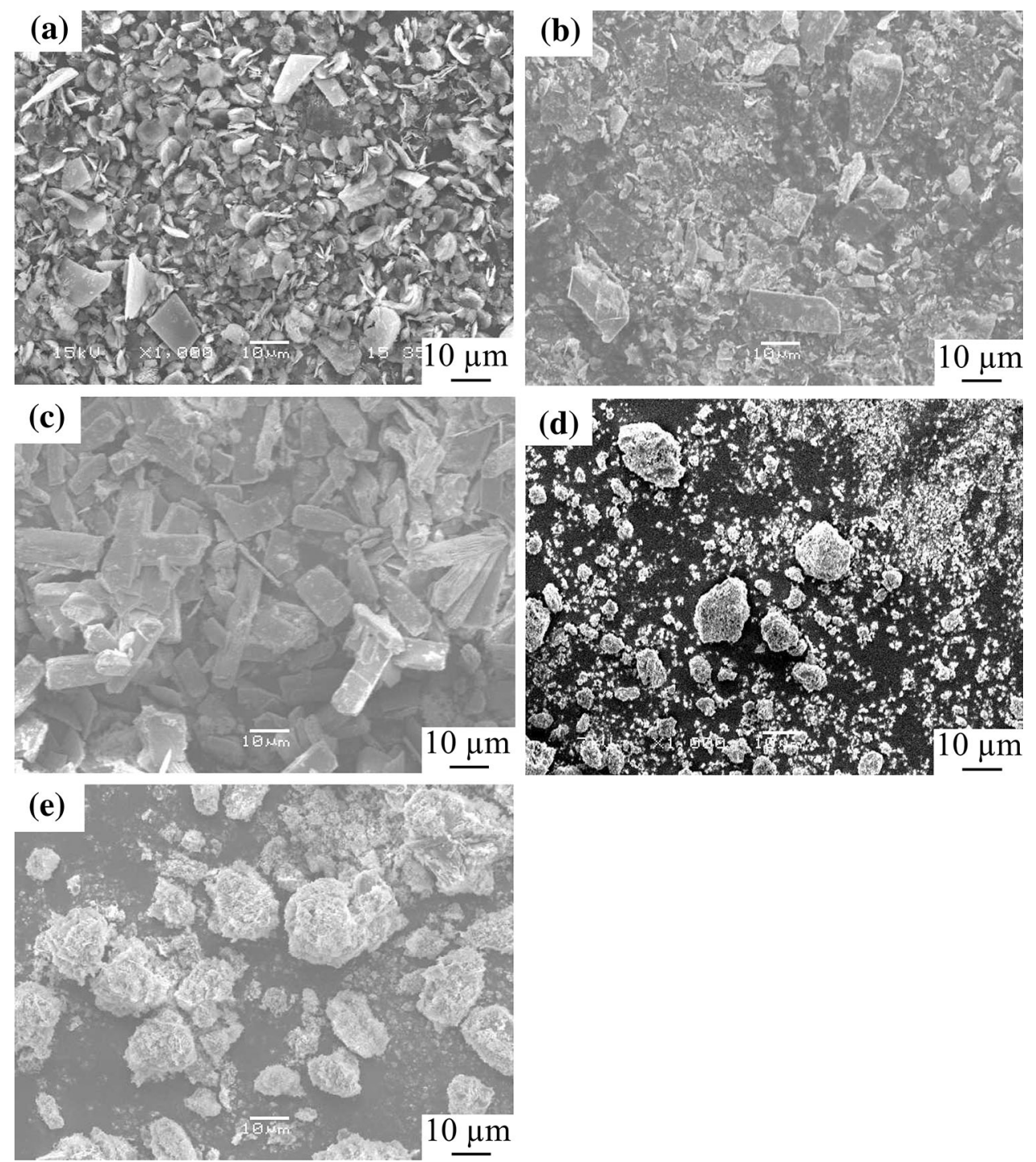

analysis of the sample powders than in the SEM image because the powders were dispersed in solution for the particle size distribution measurement. It is unclear why the particle size of the sample prepared from $\mathrm{Na}_{4} \mathrm{P}_{2} \mathrm{O}_{7}$ was larger than that observed in the SEM image. The particle size distributions of the other samples corresponded to those from the SEM images. Particles with sub-micrometer dimensions were not obtained by changing the phosphate source.

\section{Cosmetic properties of zinc phosphates}

Figure 4 summarizes the respective photocatalytic activities of the samples prepared with various phosphate sources. Zinc oxide, which is widely used as a white pigment in cosmetics, was evaluated for comparison with zinc phosphate [1]. Methylene blue decomposed under UV irradiation in the presence of zinc oxide (Fig. 4g). On the other hand, the various zinc phosphates, which are mild materials that can protect the sebum on the skin, had little photocatalytic activity irrespective of the phosphate source (Fig. 4b, f).

Figure 5 shows the UV-Vis reflectance spectra of the zinc phosphates prepared with various phosphate sources. All samples prepared in this study exhibited high reflectance within the range of visible light, irrespective of the phosphate source. Therefore, the obtained samples were white powders. The prepared samples exhibited relatively high reflectance in the range of $250-400 \mathrm{~nm}$. The sample prepared with $\mathrm{Na}_{5} \mathrm{P}_{3} \mathrm{O}_{10}$ exhibited lower reflectance in this range relative to the other samples.

Moisture helps to prevent itchiness and damage to the skin. Pigments used in cosmetics should ideally retain the moisture on the skin. Figure 6 shows the moisture retention of the samples prepared with various phosphate sources. At a given retention time, a smaller weight loss indicates high 


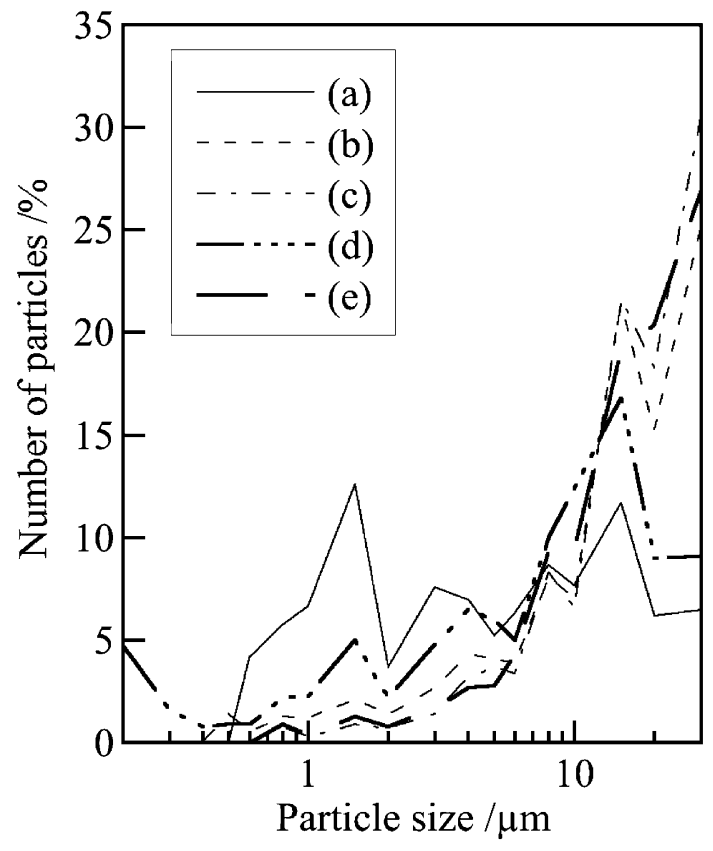

Fig. 3 Particle size distribution of samples prepared from various phosphate sources: $a \mathrm{H}_{3} \mathrm{PO}_{4}, b \mathrm{NaH}_{2} \mathrm{PO}_{4}, c \mathrm{Na}_{2} \mathrm{HPO}_{4}, d \mathrm{Na}_{4} \mathrm{P}_{2} \mathrm{O}_{7}$, and $e \mathrm{Na}_{5} \mathrm{P}_{3} \mathrm{O}_{10}$

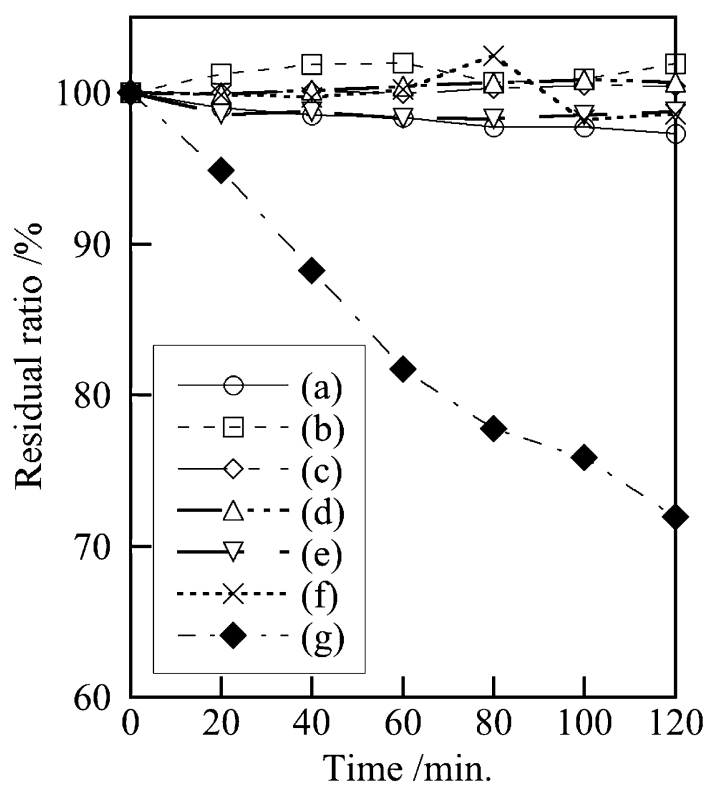

Fig. 4 Photocatalytic activity of samples prepared from various phosphate sources: $a$ blank, $b \mathrm{H}_{3} \mathrm{PO}_{4}, c \mathrm{NaH}_{2} \mathrm{PO}_{4}, d \mathrm{Na}_{2} \mathrm{HPO}_{4}$, $e \mathrm{Na}_{4} \mathrm{P}_{2} \mathrm{O}_{7}, f \mathrm{Na}_{5} \mathrm{P}_{3} \mathrm{O}_{10}$, and $g \mathrm{ZnO}$

moisture retention of the phosphate pigments. For example, at $5 \mathrm{~min}$, the sample prepared with $\mathrm{H}_{3} \mathrm{PO}_{4}$ underwent $21.6 \%$ weight loss (Fig. 6a), whereas the sample prepared with $\mathrm{Na}_{4} \mathrm{P}_{2} \mathrm{O}_{7}$ underwent $15.6 \%$ weight loss (Fig. 6d). The samples prepared with $\mathrm{Na}_{4} \mathrm{P}_{2} \mathrm{O}_{7}$ had higher water retention capacity than the sample prepared with $\mathrm{H}_{3} \mathrm{PO}_{4}$.

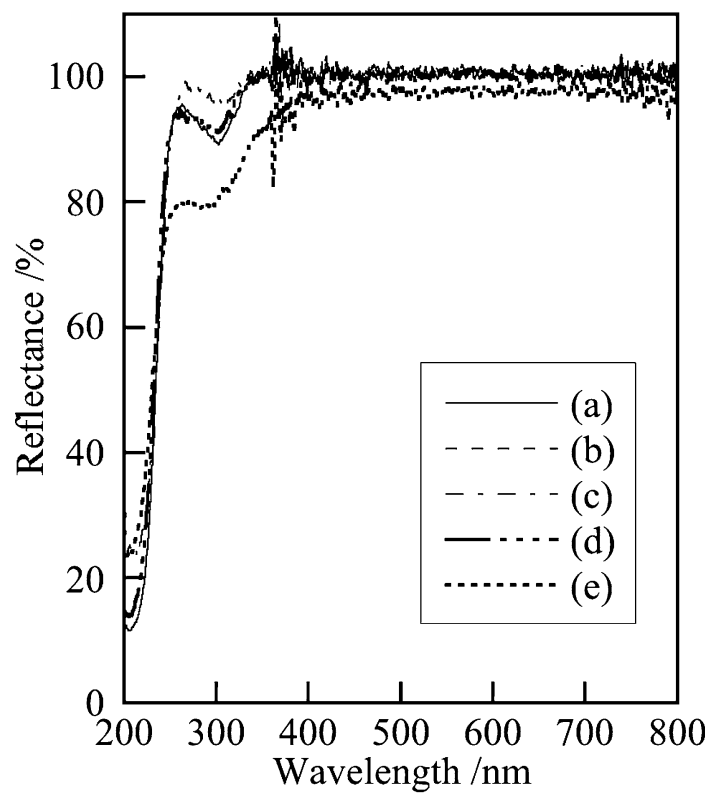

Fig. $5 \mathrm{UV}-\mathrm{Vis}$ reflectance of samples prepared from various phosphate sources: $a \mathrm{H}_{3} \mathrm{PO}_{4}, b \mathrm{NaH}_{2} \mathrm{PO}_{4}, c \mathrm{Na}_{2} \mathrm{HPO}_{4}, d \mathrm{Na}_{4} \mathrm{P}_{2} \mathrm{O}_{7}$, and $e \mathrm{Na}_{5} \mathrm{P}_{3} \mathrm{O}_{10}$

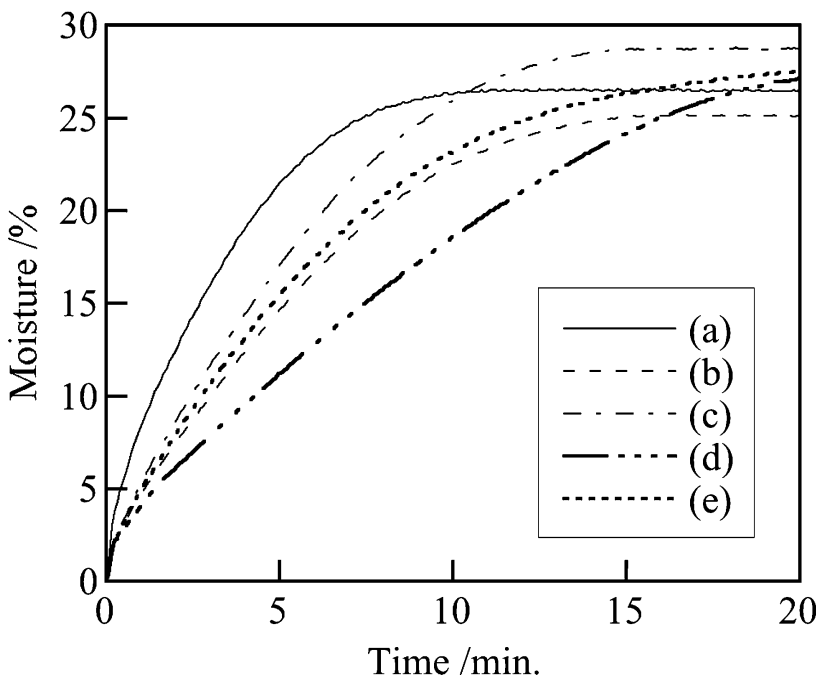

Fig. 6 Water retention of samples prepared from various phosphate sources: $a \mathrm{H}_{3} \mathrm{PO}_{4}, \quad b \quad \mathrm{NaH}_{2} \mathrm{PO}_{4}, c \mathrm{Na}_{2} \mathrm{HPO}_{4}, d \mathrm{Na}_{4} \mathrm{P}_{2} \mathrm{O}_{7}$, and $e \mathrm{Na}_{5} \mathrm{P}_{3} \mathrm{O}_{10}$

As described above, pigments with a high level of smoothness spread well across the skin, and powder smoothness is the another important factor for cosmetic applications [21]. Table 1 shows the smoothness of the samples prepared with various phosphate sources. Generally, for cosmetic application, the MIU and MMD values should ideally be less than 0.6 and smaller than 0.04 , respectively. All samples prepared in this study had sufficiently small MIU and MMD values. Small MIU and MMD values were obtained for the samples prepared with 
$\mathrm{Na}_{4} \mathrm{P}_{2} \mathrm{O}_{7}$ and $\mathrm{Na}_{5} \mathrm{P}_{3} \mathrm{O}_{10}$. These results are related to the spherical morphology observed in the SEM images.

\section{Conclusion}

Various zinc phosphates were prepared with $\mathrm{Zn}\left(\mathrm{NO}_{3}\right)_{2}$ and $\mathrm{H}_{3} \mathrm{PO}_{4}, \quad \mathrm{NaH}_{2} \mathrm{PO}_{4}, \quad \mathrm{Na}_{2} \mathrm{HPO}_{4}, \quad \mathrm{Na}_{4} \mathrm{P}_{2} \mathrm{O}_{7}, \quad$ or $\quad \mathrm{Na}_{5} \mathrm{P}_{3} \mathrm{O}_{10}$ solution. ICP and XRD analyses indicate that $\mathrm{H}_{3} \mathrm{PO}_{4}$, $\mathrm{NaH}_{2} \mathrm{PO}_{4}$, and $\mathrm{Na}_{2} \mathrm{HPO}_{4}$ yielded $\mathrm{Zn}_{3}\left(\mathrm{PO}_{4}\right)_{2} \cdot 4 \mathrm{H}_{2} \mathrm{O}$ as the main product, whereas $\mathrm{Zn}_{2} \mathrm{P}_{2} \mathrm{O}_{7}$ was obtained with $\mathrm{Na}_{4}$ $\mathrm{P}_{2} \mathrm{O}_{7}$, and $\mathrm{Zn}_{5}\left(\mathrm{P}_{3} \mathrm{O}_{10}\right)_{2}$ was obtained with $\mathrm{Na}_{5} \mathrm{P}_{3} \mathrm{O}_{10}$. The samples prepared with $\mathrm{Na}_{4} \mathrm{P}_{2} \mathrm{O}_{7}$ and $\mathrm{Na}_{5} \mathrm{P}_{3} \mathrm{O}_{10}$ comprised large spherical particles. The obtained zinc phosphates exhibit relatively low photocatalytic activity, and thus should not exert deleterious effects on sebum on the skin. This property is important for cosmetic pigments. All samples prepared in this study exhibit high reflectance within the range of visible light, irrespective of the phosphate source. The samples prepared with $\mathrm{Na}_{4} \mathrm{P}_{2} \mathrm{O}_{7}$ had higher water retention than the other samples. The sample prepared with $\mathrm{Na}_{4} \mathrm{P}_{2} \mathrm{O}_{7}$ and $\mathrm{Na}_{5} \mathrm{P}_{3} \mathrm{O}_{10}$ had low slipping resistance and roughness. Overall, the phosphate source influenced the powder properties of the zinc phosphate white pigment.

Acknowledgments Support of this work by The Cosmetology Research Foundation is gratefully acknowledged. The authors are grateful to Dr. Takeshi Toyama, Nihon University, Japan, for smoothness measurements.

Open Access This article is distributed under the terms of the Creative Commons Attribution 4.0 International License (http://crea tivecommons.org/licenses/by/4.0/), which permits unrestricted use, distribution, and reproduction in any medium, provided you give appropriate credit to the original author(s) and the source, provide a link to the Creative Commons license, and indicate if changes were made.

\section{References}

1. Diebold U (2003) The surface science of titanium dioxide. Surf Sci Rep 48(5-8):53-229

2. Senzuki M, Tamura T, Miura K, Ikarashi Y, Watanabe Y, Fujii M (2010) Study on penetration of titanium dioxide $\left(\mathrm{TiO}_{2}\right)$ nanoparticles into intact and damaged skin in vitro. J Toxicol Sci 35(1):107-113

3. Gamer AO, Leibold E, Van Ravenzwaay B (2006) The in vitro absorption of microfine zinc oxide and titanium dioxide through porcine skin. Toxicol Vitro 20(3):301-307
4. Jones DJ, Aptel G, Brandhorst M, Jacquin M, Jimenez-Jimenez J, Jimenez-Lopez A, Maireles-Torres P, Piwonski I, RodriguesCastellon E, Zajac J, Roziere J (2000) High surface area mesoporous titanium phosphate: synthesis and surface acidity determination. J Mater Chem 10(8):1957-1963

5. Bhaumik A, Inagaki S (2001) Titanium phosphate molecular sieves with ion-exchange capacity. J Am Chem Soc 123(4):691-696

6. Averbuch-Pouchat MT, Durif A (1996) Topics in phosphate chemistry. World Scientific Publishing Co. Pte. Ltd, Singapore

7. Hammas I, Horchani-Naifer K, Ferid M (2010) Conduction properties of condensed lanthanum phosphates: $\mathrm{La}\left(\mathrm{PO}_{3}\right)_{3}$ and $\mathrm{LaP}_{5} \mathrm{O}_{14}$. J Rare Earths 28(3):321-328

8. Raynaud S, Champion E, Bernache-Assollant D, Thomas P (2002) Calcium phosphate apatites with variable $\mathrm{Ca} / \mathrm{P}$ atomic ratio $\mathrm{I}$. Synth Charact Thermal Stab Powders Biomater 23(4):1065-1072

9. Boonchom B, Danvirutai C, Maensiri S (2008) Soft solution synthesis, non-isothermal decomposition kinetics and characterization of manganese dihydrogen phosphate dihydrate $\mathrm{Mn}\left(\mathrm{H}_{2}\right.$ $\left.\mathrm{PO}_{4}\right)_{2} \cdot 2 \mathrm{H}_{2} \mathrm{O}$ and its thermal transformation products. Mater Chem Phys 109(2-3):404-410

10. Rathan SV, Govindaraj G (2010) Thermal and electrical relaxation studies in $\left.\mathrm{Li}_{(4+} x\right) \mathrm{Ti}_{x} \mathrm{Nb}_{1 \_} x \mathrm{P}_{3} \mathrm{O}_{12}(0.0 \leq x \leq 1.0)$ phosphate glasses. Solid State Sci 12(5):730-735

11. Onoda H, Nariai H, Moriwaki A, Maki H, Motooka I (2002) Formation and catalytic characterization of various rare earth phosphates. J Mater Chem 12(6):1754-1760

12. Onoda $H$, Yamaguchi $T$ (2012) Influence of ultrasonic treatment on preparation and powder properties of titanium phosphates. J Mater Chem 22(37):19826-19830

13. Onoda H, Yamaguchi T, Takenaka A (2012) Synthesis and pigmental properties of titanium phosphates with the addition of urea. Int J Cosmet Sci 34(1):86-90

14. Onoda H, Haruki M, Toyama T (2014) Preparation and powder properties of zinc phosphates with additives. Ceram Int 40(2):3433-3438

15. Onoda H, Yamaguchi $\mathrm{T}$ (2014) $\mathrm{pH}$-controlled hydrothermal synthesis of titanium phosphates and their powder properties. J Adv Ceram 3(4):326-331

16. Onoda H, Yamaguchi T (2013) Preparation of titanium phosphates with sodium triphosphate in hydrothermal process and their powder properties for cosmetics. Adv Mater Chem Phys 3(1): $1-6$

17. Ramaswamy V, Jagtap NB, Vijayanand S, Bhange DS, Awati PS (2008) Photocatalytic decomposition of methylene blue on nanocrystalline titania prepared by different methods. Mater Res Bull 43(5):1145-1152

18. Du P, Bueno-Lopez A, Verbaas M, Almeida AR, Makkee M, Moulijn JA, Mui G (2008) The effect of surface OH-population on the photocatalytic activity of rare earth-doped $\mathrm{P} 25-\mathrm{TiO}_{2}$ in methylene blue degradation. J Catal 260(1):75-80

19. Mills A (2012) An overview of the methylene blue ISO test for assessing the activities of photocatalytic films. Appl Catal B 128:144-149

20. Whitaker A (1975) The crystal structure of hopeite, $\mathrm{Zn}_{3}\left(\mathrm{PO}_{4}\right)_{2}$ $4 \mathrm{H}_{2} \mathrm{O}$. Acta Cryst B 31:2026-2035

21. Cheng SY, Yuen CWM, Kan CW, Cheuk KKL, Tang JCO, Li SY (2009) A comprehensive study of silicone-based cosmetic textile agent. Fibers Polym 10(1):132-140 